\title{
Performance of Marhata Unjuk in Batak Toba Wedding
}

\author{
Immanuel Silaban, Robert Sibarani, Hamzon Situmorang, and Dwi Widayati \\ University of Sumatera Utara, Medan, Indonesia
}

\section{Abstract}

Batak Toba ethnic has a wealth of culture. One of them is the wedding. The wedding is a bond carried out by human witnessed by the families of bride and bridegroom and held in accordance with the applicable rules in their respective environment to build a new household. One of the parts of Batak traditional wedding is marunjuk, in which the implementation is guided by Dalihan Natolu (as the third cultural value with the attitudes) and led by a Raja Parhata (The customary performer in Toba Batak life cycle stages of customary traditions). This article is discussed with the anthropolinguistic approach, which focuses on the text, context, and co-text conveyed by Parhata (guide to the course of the ceremony). The study is descriptive qualitative using Miles' and

Corresponding Author: Immanuel Silaban

silabanimmanuel94@gmail.com

Received: 1 July 2019

Accepted: 18 July 2019

Published: 31 July 2019

Publishing services provided by Knowledge

(c) Immanuel Silaban et al. This article is distributed under the terms of the Creative Commons

Attribution License, which

permits unrestricted use and redistribution provided that the original author and source are credited.

Selection and Peer-review under the responsibility of the AICLL 2019 Conference Committee. Huberman's methods (1988) to analyze the data. The purpose of qualitative research is to find the performance of marhata unjuk Batak Toba wedding. The results of this study were obtained by looking at the language performance delivered by Parhata in marunjuk ceremony, namely the delivered text, co-text or the accompanying text and the context of the conversation in the ceremony.

Keywords: Anthropolinguistic, Marhata unjuk, Performance

\section{Introduction}

The Toba Batak community has various cultures and customs. One of them is a traditional wedding. Wedding is a combination of the essence of life between men and women into one in fostering a new household. As in other ethnics, wedding in the Toba Batak is a must for every human being, besides the natural vocation, it is also considered sacred and happiness to continue the offspring.

The traditional wedding is a bond carried out by human beings witnessed by the families of both parties and held in accordance with the applicable rules in their respective environment to build a new household. The wedding for the Toba Batak community is one of the customs that is very concerned with speaking. Language plays an important role in supporting the wedding. (Gurning, 2004: 15).

Marunjuk (traditional wedding event or traditional party) is an event during the wedding of the traditional Toba Batak. At this marunjuk event, the steps of weddings will 
be held starting from 1) Marsibuha-buhai, which means the beginning of the marunjuk (ceremony of unjuk), 2) Manjalo pasu-pasu parbagason, which means accepting the blessing of wedding in a church, 3) Panomu-nomuan which means the procession of entering the venue of the event that held by welcoming and receiving all invitations, 4) pasahat tudu-tudu sipanganon dohot dengke simudur-udur which means the surrender of signs of traditional Toba Batak food, 5) pasahat tumpak that means giving a donation to the groom's family which is the party of all invitations or relatives, 6) pasahat sinamot, which means giving dowry 7) Mangulosi, which means giving ulos to the bride and family while giving advice, 8) Paulak une, which means the bridegroom's family brings tudu-tudu ni sipanganon (portions of meat) which will be given to the bride's family, 9) Mangujungi ulaon which means the closing event where the performance party will be officially finished by concluding all the customary events (Simatupang, 2016: 66).

In the wedding tradition, the Toba Batak people, especially in the marunjuk event, are controlled by a spokesman called Raja Parhata (The customary performers in Toba Batak life cycle stages of customary traditions). The success of the marhata event in the dominant Batak Toba traditional ceremony was determined by a spokesman.

A Raja parhata must understand all the intricacies of Batak customs in general and the customs applicable to the family members in particular. It absolutely concerns the history of the Batak ethnic, including an understanding of its culture which includes the kinship system of Dalihan Natolu (as the third cultural value with the attitudes of somba marhula-hula "being respectful for the wife giver", elek marboru " being persuasive to the wife receiver", manat mardongan tubu "becareful to the same surename"), customs, genealogies, speech language, use of ulos (Tradition woven cloth), distribute of jambar (distribution in the form of meat to someone who is entitled to receive according to traditional Batak), and others that deserves to know (Pardede et al. 1981: 90-91).

This paper aims to determine the performance of marhata unjuk by using the approach of the anthropolinguistic concept, which focuses on the text, context, and co-text that conveyed by Raja Parhata that can be used as a material for learning to know about marunjuk at the Toba Batak wedding.

\section{Literature Review}

\subsection{Anthropolinguistics}

Anthropolinguistics focuses on the relationship between language and culture in a society (Sibarani 2004: 20). Kridalaksana, then, uses the term anthropolinguistic study 
as a study of linguistic language, while this linguistic language is a branch of linguistics that discusses the variation and use of language in relation to language patterns and language relations related to social groups, religion, work and kinship (Sibarani 2011: 134).

Linguistic anthropology, is also called ethnolinguistics analyzes not only its structure but also its function and usage in the context of socio-cultural situations. Through linguistic anthropology, we look at what people do with language and speech produced; silence and gesture associated with the context of its appearance (Duranti, 2001: 1).

In study of language, culture, and other aspects of human life, the attention or the main focus of anthropolinguistic is emphasized on three important topics, namely performance, indexicality, participation (participation). Through performance, language is understood in the process of activities, actions, and communicative performances, which require creativity. Language as a lingual element that stores cultural resources cannot be understood separately from the performance or language activities (Duranti, 1977: 14).

\subsection{Marhata}

Marhata is an official dialogue between two parties, namely the bride's parents and the groom's parents who are usually preceded by a joint meal. Marhata is to discuss and realize the purpose of each traditional ceremony by using the language of parhataan speech, (Pardede, T. Bertha, 1981: 7)

\section{Research Method}

This research is a qualitative descriptive study by using descriptive inductive methods that data is used purely and naturally by looking at the patterns that exist in conversations on the performance of the Toba Batak wedding, so the results of this research explain the actual reality. The purpose of qualitative research is to find the performance of marhata unjuk Toba Batak wedding.The location of this study is in the Tipang, district of Humbang Hasundutan, North Sumatra Province.

The method of collecting primary data "marhata unjuk" event that applied in this study is the Observation Method, both participatory observation (Direct, Participatory Observation) and Non-Participatory Observation. The researcher observes the description of activities, behavior, actions, social interactions, and social processes of the Toba Batak community, observes without participation, raises the verbalized information, and 
also follows scientific background. This method is applied by recording and photo techniques through video tapes. This technique is used for data collection in the form of conversations when the event of marhata marunjuk. Then the data was taken by recording techniques in the form of transcription. Then, the form and content of the speeches on the traditional wedding events that have been transcribed from the Toba Batak language are translated into Indonesian.

The collection method of the secondary data of "marhata unjuk" is Library Method as supporting data of primary data. This method is applied by taking notes. Speeches that are not clear, especially the use of umpasa and incomplete language are compared with existing library data. In addition, the interview method from spokesman is also applied to know the meaning of speech and the relevance of the every response from the spokesperson and to reading the data with several other spokesmen (triangulation). The procedure according to the model of Miles and Huberman was used to analyze in this study. (Miles and Huberman, 1988: 23)

\section{Result and Discussion}

\subsection{Performance of Marhata unjuk the ceremonial wedding Batak Toba}

The batak's tradition party is held every where, that is not as same as the reception party that ever seen in the city. The party means to give congratulations to the people who have the party by guest or just listen a speech or advice after or before the guests are invited to eat. It is not as same as the party that asks the guests to eat with the French people's way of having dinner without waiting for other guests. On the other hand, in Batak's tradition party, we can see some programmees which are arranged based on traditional rule. The Bataknese, any where, who are involved in this tradition will do all the programmes. The party of Bataknese tradition is visible for us as to have a communal feeling based on the principle of Dalian Na Tolu, if it is not based the tradition, Dalian Na Tolu, this is not batak's traditional party.

The inviter, who is wife or husband is called Suhut. Husband can not separate from all his brothers with their each wife. All of them are Suhut. The owner of the party is called Si Sada Hasuhuton. So, to make distinction between Si Sada Hasuhuton and the host, therefore the host is called Suhut Tangkas or Suhut Sihabolonan. Suhut tangkas usually arranges the programme passively. He is only given a chance to Mangampu. He is usually to say thanks to all of the guests before the party is over. 
The traditional wedding is held at the house of the person who holds the party. The mother in law is invited as well as their lineage and their bori. They sit face to face on the mat, in where the party is done. Suhut their similar liniage and boru sit at one side, while on the other side, the father in law with their similar lineage and boru sit in front of the suhut. They are hula-hula from the host.

There are two inviters, namely the man's parents and the woman parents. Father in law with his group always brings rice in storage bag (Tandok) if they come to the boru's party. The rice is brought namely the rice of soul strengthener (Boras Si pirni Tondi). The rice will give an important meaning according to bataknese ancertor. It shows the hope which can be seen in the proverd: "Horas Tondi Madingin, Pir Tondi Matogu". it can be concluded in one word namely Horas (congratulation). Besides, the father in law also brings Dengke Sitio-tio (gold fish) which is give to son in law. Dengke sitio-tio usually is gold fish which is put on the small tray.

Pesta unjuk is a joyous celebration of the wedding of sons and daughters. The men's parties called it with the term "marunjuk" and the women's parties called it mangan boli or mangan juhut ni boru (eat a plate of pork given by the bride's family).

\subsection{Text analysis marhata unjuk in the wedding of the Toba Batak}

\subsubsection{Text on the marhata marunjuk event that is conducted by Raja Parhata}


TABLE 1: Text on the Marhata Marunjuk Event by Parhata Paranak.

\begin{tabular}{|c|c|c|}
\hline RAJA PARHATA & $\begin{array}{l}\text { TEXT on the MARHATA } \\
\text { MARUNJUK }\end{array}$ & MEANING \\
\hline Parhata Paranak & $\begin{array}{l}\text { Mauliate ma di Tuhanta, ala asi ni } \\
\text { roha-Na boi hita marpungu di } \\
\text { bagasan manogot on. Raja nami, } \\
\text { bangko do di hita jolma, molo balga } \\
\text { anak pangolihononhon, magodang } \\
\text { boru pamulion. Tangkas di na laho } \\
\text { mamungka buha ni ari on hita, di } \\
\text { buha ni na uli, di na laho mamboan } \\
\text { anak dohot parumaenku tu bagas } \\
\text { joro ni Tuhanta annon, ima boru ni } \\
\text { raja i dohot anak nami. Laho } \\
\text { manjalo pasu-pasu parbagason } \\
\text { pardongan saripeon sian Tuhanta } \\
\text { marhite-hite naposo-Na. Asa gabe } \\
\text { sada keluarga na imbaru nasida di } \\
\text { tonga-tonganta, ima anak nami na } \\
\text { gabe helamu dohot boru muna na } \\
\text { gabe parumaen nami. Mardomu tu } \\
\text { si raja nami, ro hami nuaeng } \\
\text { mandapothon raja nami di bagasan } \\
\text { manogot on ima na laho } \\
\text { pasahathon tudu-tudu ni } \\
\text { sipanganon tu hamu na hula-hula } \\
\text { nami na huparsangapi, parhitean } \\
\text { nami pasangaphon raja hula-hula } \\
\text { nami. Molo tung songoni pe ulaon } \\
\text { namasa on, dang na holit nami, } \\
\text { dang tois nami. Tung songoni pe na } \\
\text { boi tarpatupa hami, las ma roha } \\
\text { muna manjalo raja nami. Songon } \\
\text { hata ni natua-tua mandok: } \\
\text { Sitiptip ma sigompa } \\
\text { Golang-golang pangarahutna } \\
\text { Otik so sadia pe na tupa } \\
\text { Sai godang ma pinasuna las ma } \\
\text { roha muna manjalo }\end{array}$ & $\begin{array}{l}\text { Married male family (parboru) } \\
\text { respecting hula-hula by providing } \\
\text { food }\end{array}$ \\
\hline
\end{tabular}




\begin{tabular}{|c|c|c|}
\hline RAJA PARHATA & $\begin{array}{l}\text { TEXT on the MARHATA } \\
\text { MARUNJUK } \\
\text { Thanks God, because of His } \\
\text { blessings so we can gather this } \\
\text { morning. Our king, it has become a } \\
\text { habit for us, if our sons and our } \\
\text { daughters are adults, they must be } \\
\text { married. We will start today, start } \\
\text { well, to bring my son and } \\
\text { daughter-in-law to the house of } \\
\text { worship of God, namely the } \\
\text { daughter of the king and our child. } \\
\text { They will receive the blessing of } \\
\text { wedding from our Lord through the } \\
\text { Pastor. In order for them to become } \\
\text { a new family in our family, our son is } \\
\text { your son-in-law and your daughter is } \\
\text { our son-in-law. For that, our king, we } \\
\text { are coming now to visit our king this } \\
\text { morning to give tudu-tudu ni } \\
\text { sipanganon (portions of meat) to the } \\
\text { hula that we respect with the aim of } \\
\text { honoring our hula-hula. Even though } \\
\text { this traditional party look like this, } \\
\text { not because we are stingy, not } \\
\text { because we are arrogant. If this is } \\
\text { what we can give, rejoice in } \\
\text { accepting this, our king. As the } \\
\text { proverb says: } \\
\text { Sitiptip ma sigompa } \\
\text { Golang-golang pangarahutna } \\
\text { Otik so sadia pe na tupa } \\
\text { Sai godang ma pinasuna } \\
\text { Have a lot of blessings and rejoice } \\
\text { to receive it }\end{array}$ & MEANING \\
\hline Parhata Parboru & $\begin{array}{l}\text { Mauliate ma Amangboru. Ido } \\
\text { tingkos do songon na didok muna i. } \\
\text { la nunga tangkas dipaboa } \\
\text { Amangboru taringot tu ulaonta } \\
\text { sadari on, ima na laho mamboan } \\
\text { boru nami dohot hela nami tu bagas } \\
\text { joro ni Tuhanta i. Asa anggiat gabe } \\
\text { sada keluarga na imbaru nasida di } \\
\text { tonga-tonganta. Di hamu } \\
\text { Amangboru nami, di son hupasahat } \\
\text { hami dengke simudur-udur, dengke } \\
\text { na mokmok dohot indahan na las, } \\
\text { anggiat ma tu ari na naeng ro lam } \\
\text { tu mokmok na hamu saluhutna } \\
\text { dohot lam tu las na ma angka } \\
\text { partondion muna. Rap mudur hamu } \\
\text { tu dolok dapotan las ni ari, mudur tu } \\
\text { toruan dapotan mual na tio. Dung i, } \\
\text { asa rap sarapan ma hita saluhutna } \\
\text { dohot laos sae on ma hita borhat } \\
\text { mamboan boru dohot helaku tu } \\
\text { bagas joro ni Tuhan i. Asa songon } \\
\text { na didok ni natua-tua: } \\
\text { Sahat-sahat ni solu } \\
\text { Sahat ma tu topi ni tao } \\
\text { dengke na hupasahat hami } \\
\text { Las ma roha muna manjalo }\end{array}$ & $\begin{array}{l}\text { Women's family (hula-hula) present a } \\
\text { giving of fish to man's family } \\
\text { (parboru) to give sign of gratitude for } \\
\text { being treated in the wedding. }\end{array}$ \\
\hline
\end{tabular}




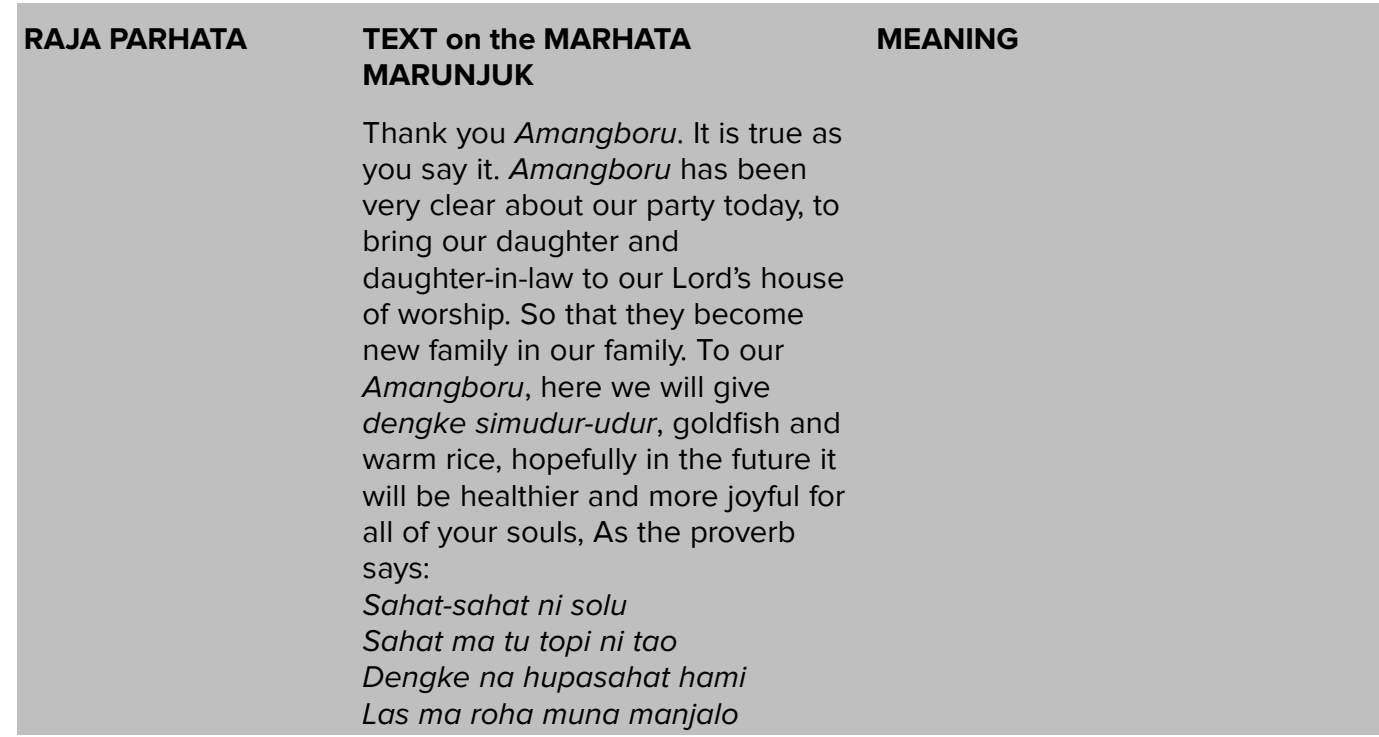

The text is delivered by the Raja parhata paranak to the bride's family that contains umpasa or Batak's poem "Sitiptip ma sigompa Golang-golang pangarahutna, Otik so sadia pe na tupa Sai godang ma pinasuna las ma roha muna manjalo" indicates that through the umpasa, their giving had conveyed happiness to those who received it.

\subsubsection{Co-text in Marunjuk traditions}

Co-text as a complement to the text that delivered by Parhata in the marunjuk event is in the form of dengke sitio-tio and in the form of Tudu-tudu sipanganon (portions of meat), that the literal meaning of the banquet marker (commonly called in batak tradition is na margoar). Tudu-tudu sipanganon is a certain parts of animal slaughter which are placed in the middle as a symbol of Hasuhuton respect to the invitation, especially to Hula-hula (woman's family).

\subsubsection{Context of Marunjuk traditions}

The context that is in the point of view in the custom of the Toba Batak wedding is the Idiology context. The ideology context of Marunjuk at the Toba Batak wedding party as a belief system of the Toba Batak indigenous people views custom as a customary belief adapted to Dalihan Natolu.

In the marunjuk traditions, the male family (parboru) respected the Woman family called Hula Hula by giving Tudu - tudu sipanganon (potions of meat) and the woman 
Family (Hula - hula) rewarding them with Dengke simudur-udur( gold fish) as a sign of gratitude to the man family (boru).

\section{Conclusion}

Based on the previous analysis and discussion, a number of conclusions were stated as follows: In the marhata unjuk at the Toba Batak wedding, the following are:

1. At this marunjuk event all weddings will be held starting from 1) Marsibuha-buhai, which means the beginning of the show (demonstration party), 2) Manjalo pasupasu parbagason means accepting the blessing of wedding in a place of worship, 3) Panomu-nomuan, which means the procession of opening the venue for the event was held by welcoming and receiving all invitations, 4) pasahat tudu-tudu sipanganon dohot dengke simudur-udur which means the surrender of signs of traditional Toba Batak food, 5) pasahat tumpak that means giving a donation to the groom's family which is the party of all invitations or relatives, 6) pasahat sinamot means giving dowry 7) Mangulosi, it means giving ulos to the bride and family while giving advice, 8) Paulak une, that means the bridegroom's family brings tudutudu ni sipanganon (portions of meat) which will be given to the bride's family, 9) Mangujungi ulaon meaning the closing event where the marhata unjuk ceremony will be officially finished by concluding all the customary events.

2. In the marunjuk ceremony the man family (Boru) gives Tudu-Tudu Sipanganon and the woman family (Hula-hula) to give Goldfish as a sign of mutual respect in the traditional wedding traditition in Toba Batak.

\section{References}

[1] Duranti, Alesandro (ed). (2001). Linguistic Anthropology. Messachusetts: Blackwell

[2] Duranti, Alesandro. (1977). Linguistic Anthropology. Cambridge: Cambridge University press

[3] Gurning, Tardus. (2004). Sistem Tatakrama Berbahasa Batak Toba pada Upacara Adat Perkawinan. Medan: Fakultas IImu Budaya USU.

[4] Miles, M. B., and Huberman, M.A. (1988). Qualitative data Analysis. London: Sage Publication 
[5] Pardede T, Bertha, et al (1981). Bahasa Tutur Parhataan dalam Upacara Adat Batak Toba. Jakarta: Pusat Pembinaan dan Pengembangan Bahasa Departemen Pendidikan dan Kebudayaan

[6] Pardede, R.A. Limongga. (2010). Masisean di Ulaon Adat Batak Tobs. Medan: publisher not identified.

[7] Sibarani, Robert. (2000). Deskripsi Wacana Adat Perkawinan dalam Masyarakat Batak Toba. Medan: USU.

[8] Sibarani, Robert. (2004). Antropolinguistik. Medan: Poda

[9] Sibarani, Robert. (2012). Kearifan Lokal "Hakekat, Peran, dan Metode Tradisi Lisan". Jakarta: Asosiasi Tradisi Lisan.

[10] Simatupang. 2016. Adat Budaya Batak dan Biografi. Tangerang: Bornrich Publishing. 